\title{
ANALISIS EKONOMI KEBIJAKAN DANA DESA TERHADAP KEMISKINAN DESA DI KABUPATEN TULUNGAGUNG
}

\author{
Intan Mala Sari \\ M. Faisal Abdullah \\ Jurusan Ilmu Ekonomi dan Studi Pembangunan \\ Fakultas Ekonomi dan Bisnis \\ Universitas Muhammadiyah Malang \\ Email: intanmalasari5@gmail.com
}

\begin{abstract}
The purpose of this research is analysis of the difference rural poverty in district tulungagung between on the 2015 and 2016 and analyze influence of fund village and ADD against rural poverty in Tulungagung district. Analysis tools used twin regression with the panel data to hypothesis testing with $F$ test, $t$ test, and coefficient of determination $\left(R^{2}\right)$ at the error level $\alpha=5 \%$. The result of analysis regression panel data with the selected model is Fixed Effect Model that show difference rural poverty in district tulungagung between on the 2015 and 2016, variables used in the model are the village fund and ADD take effect on rural poverty with the every score -4,52 for the village fund and-1,52 for ADD. While the coefficient of determination $\left(R^{2}\right)$ is 0,99 or $99 \%$, variable ability show village fund and ADD explain rural poverty in the tulungagung district is $99 \%$. And influence of fund village and ADD against rural poverty is there any difference at the every village in Tulungagung district.
\end{abstract}

Keywords: the fund village, $A D D$, rural poverty.

\begin{abstract}
Abstrak
Tujuan dari penelitian ini untuk menganalisis perbedaan kemiskinan desa di Kabupaten Tulungagung antara Tahun 2015 dengan 2016 dan untuk menganalisis pengaruh Dana Desa dan ADD terhadap kemiskinan desa di Kabupaten Tulungagung tahun 2015-2016. Alat analisis yang digunakan adalah regresi berganda dengan data panel yang kemudian dilakukan pengujian hipotesis dengan uji F, uji t, dan Koefisien Determinasi $\left(R^{2}\right)$ pada tingkat kesalahan $\alpha=5 \%$. Hasil analisis regresi data panel dengan model terpilih adalah Fixed Effect Model menunjukkan bahwa terjadi perbedaan kemiskinan desa di Kabupaten Tulungagung antara tahun 2015 dengan 2016, variabel yang digunakan dalam model yaitu Dana Desa dan ADD berpengaruh terhadap kemiskinan desa dengan nilai masing-masing -4,52 untuk Dana Desa dan -1,52 untuk ADD. Sedangkan nilai koefisien determinasi $\left(R^{2}\right)$ adalah 0,99 atau $99 \%$, ini menunjukkan bahwa kemampuan variabel Dana Desa dan ADD dalam menjelaskan kemiskinan desa adalah sebesar $99 \%$.
\end{abstract}

Kata Kunci: Dana Desa, ADD, Kemiskinan Desa.

\section{PENDAHULUAN}

$\begin{array}{rlr}\text { Konsekuensi } & \text { logis lahirnya } \\ \text { konsep otonomi } & \text { daerah adalah }\end{array}$ hadirnya desentralisasi fiskal. Sistem desentralisasi fiskal yang berlangsung dengan melibatkan desa 
sebagai sasaran distribusinya melahirkan implikasi pada kebijakan transfer dana dari pemerintah pusat dan pemerintah daerah kepada pemerintah desa. Dalam kerangka otonomi desa, segala bentuk urusan pemerintahan desa menjadi kewenangan desa, termasuk dalam hal pengelolaaan keuangan desa (Prasetyo, 2014).

Dalam rangka menciptakan landasan yang kuat dalam melaksanakan pengelolaan keuangan desa, pemerintah dan DPR Republik Indonesia menerbitkan UndangUndang Nomor 6 Tahun 2014 tentang Desa. Undang-Undang tersebut mencantumkan pengaturan mengenai keuangan desa dan aset desa. pasal 72 ayat 1 huruf $b$ menyebutkan bahwa pendapatan desa bersumber dari Anggaran Pendapatan dan Belanja Negara. Untuk memberikan pedoman lebih lanjut mengenai pendapatan desa, pemerintah menerbitkan Peraturan Pemerintah Nomor 60 Tahun 2014. Pendapatan desa yang dimaksud adalah Dana Desa (Abidin, 2015).

Dana Desa merupakan dana yang bersumber dari Anggaran Pendapatan dan Belanja Negara
(APBN) diperuntukkan bagi desa ditransfer melalui Anggaran Pendapatan dan Belanja Daerah Kabupaten/Kota. Dana Desa (DD) dimaksudkan sebagai bantuan stimulan atau dana perangsang untuk mendorong dalam membiayai program Pemerintah Desa. Data menunjukkan pada Tahun 2015 jumlah Dana Desa di Jawa Timur adalah sebesar Rp1.161.076.912.591 (Kementerian Keuangan RI, 2014). Tujuan penggunaan Dana Desa di dalamnya adalah untuk membiayai penyelenggaraan pemerintahan, pelaksanaan pembangunan, pembinaan kemasyarakatan dan pemberdayaan masyarakat. Dana Desa diprioritaskan untuk pembangunan desa (Peraturan Pemerintah Nomor 60 Tahun 2014). Selain itu, sumber pendapatan desa yang lain adalah Alokasi Dana Desa (ADD).

Alokasi Dana Desa (ADD) merupakan dana yang dialokasikan oleh pemerintah Kabupaten/Kota untuk desa yang bersumber dari bagian dana perimbangan keuangan pusat dan daerah yang diterima oleh Kabupaten (Peraturan Pemerintah Nomor 72 Tahun 2005). Alokasi 
Dana Desa (ADD) merupakan dana yang cukup signifikan bagi Desa untuk menunjang program-program Desa. Salah satu tujuan dari Alokasi Dana Desa (ADD) adalah pengentasan kemiskinan (Peraturan Menteri Dalam Negeri Nomor 37 Tahun 2007). Akan tetapi seiring dengan besarnya jumlah Dana Desa, masalah kemiskinan masih sulit untuk diselesaikan (Abidin, 2015).

\section{Masalah} kemiskinan merupakan salah satu perosalan mendasar yang menjadi pusat perhatian pemerintah karena terbilang cukup sulit untuk mengatasinya. Terkadang ada kalanya suatu kemiskinan harus benar-benar terjadi karena adanya suatu kondisi yang memaksa seseorang untuk miskin misalnya krisis ekonomi, juga gaya hidup dan budaya yang justru mengakibatkan masyarakat Indonesia itu menjadi miskin. Hal tersebut diperparah dengan banyaknya rumah tangga yang berada di sekitar garis kemiskinan (Astuti, 2012).

Garis kemiskinan didasarkan pada pendapatan mempertimbangkan pada dimensi kesejahteraan. Namun, ukuran ini justru tidak menggambarkan batas kemiskinan yang sebenarnya. Pasalnya, banyak orang yang mungkin tidak tergolong miskin dari segi pendapatan dikategorikan sebagai miskin atas dasar kurangnya akses terhadap pelayanan dasar serta rendahnya indikator-indikator pembangunan manusia. Selain itu, perbedaan antar daerah juga merupakan ciri kemiskinan, diantaranya tercermin dengan adanya perbedaan antara daerah perdesaan dan perkotaan. Kemiskinan lebih dominan terjadi di masyarakat perdesaan (Bank Dunia, 2000). Seperti halnya kemiskinan di Kabupaten Tulungagung.

\section{Kabupaten Tulungagung} merupakan salah satu kabupaten di Provinsi Jawa Timur bagian selatan dengan jumlah penduduk berdasarkan data profil daerah tahun 2014 mencapai 1.021,19 juta jiwa. Sedangkan jumlah penduduk miskin pada tahun 2014 adalah 89 ribu jiwa. Adapun jumlah penduduk miskin terbanyak di daerah perdesaan dengan jumlah 55,85 ribu jiwa atau 62,76 persen dari seluruh penduduk miskin (Badan Pusat Statistik Tulungagung, 2014). 
Berdasarkan latar belakang tersebut di atas, maka rumusan masalah yang diajukan dalam penelitian ini adalah: pertama, bagaimanakah pengaruh Dana Desa dan Alokasi Dana Desa (ADD) terhadap kemiskinan desa di Kabupaten Tulungagung tahun 20152016. Kedua, apakah terdapat perbedaan kemiskinan desa di Kabupaten Tulungagung antara Tahun 2015 dengan 2016.

Sehingga tujuan dari penelitian ini adalah: pertama, untuk mengetahui pengaruh Dana Desa dan Alokasi Dana Desa (ADD) terhadap kemiskinan desa di Kabupaten Tulungagung tahun 2015-2016. Kedua, untuk mengetahui perbedaan kemiskinan desa di Kabupaten Tulungagung antara Tahun 2015 dengan 2016.

Berdasarkan uraian di atas maka dapat diketahui bahwa Dana Desa maupun ADD memiliki potensi besar untuk mengentaskan kemiskinan, sehingga perlu untuk segera dilakukan penelitian yang berjudul "Analisis Ekonomi Kebijakan Dana Desa Terhadap Kemisknan Desa di Kabupaten Tulungagung."

\section{METODE PENELITIAN}

Lokasi penelitian dilakukan di 127 desa di Kabupaten Tulungagung dengan kriteria tertentu kepada Desa yang terdapat penduduk miskin, pernah menerima Dana Desa, dan desa tersebut memiliki laporan pertanggungjawaban. Jenis penelitian adalah penelitian yang besifat explanatory yaitu penelitian yang menjelaskan hubungan kausal variabel-variabel melalui pengujian hipotesis (Kuncoro, 2013).

Populasi yang digunakan dalam penelitian ini adalah seluruh desa di Kabupaten Tulungagung, yang terdiri dari 257 desa.

Teknik penentuan sampel yang digunakan adalah purposive sampling yaitu teknik penentuan sampel dengan kriteria tertentu kepada Desa yang terdapat penduduk miskin, pernah menerima Dana Desa, dan desa tersebut memiliki laporan pertanggungjawaban.

Populasi yang digunakan dalam penelitian ini adalah seluruh desa di Kabupaten Tulungagung, yang terdiri dari 257 desa. Teknik penentuan sampel yang digunakan adalah purposive sampling yaitu teknik penentuan sampel dengan 
kriteria tertentu kepada Desa yang terdapat penduduk miskin, pernah menerima Dana Desa, dan desa tersebut memiliki laporan pertanggungjawaban. Berdasarkan teknik dan kriteria pengambilan sampel, sampel pada penelitian ini yaitu 127 desa di Kabupaten Tulungagung.

Variabel yang digunakan dalam penelitian ini adalah variabel dependen yaitu kemiskinan desa yang diukur dengan jumlah penduduk miskin, variabel independen adalah Dana Desa (X1) dan Alokasi Dana Desa (X2). Sedangkan jenis data adalah data sekunder, yang diperoleh dari Badan Perencanaan Pembangunan Daerah dan Dinas Pemberdayaan Masyarakat dan Pemerintahan Desa Kabupaten Tulungagung Tahun 2015-2016 sebagai sumber data. Teknik pengumpulan data dengan melakukan dokumentasi.

Teknik analisis data yang digunakan dalam penelitian ini adalah analisis regresi dengan data panel yang bersifat statis dengan model double log. Dengan persamaan sebagai berikut:

$$
\begin{aligned}
& \log Y=\beta_{0}+\beta_{1} \log X_{1}+\beta_{2} \log X_{2}+ \\
& D i+e \ldots \ldots \ldots \ldots \ldots \ldots \ldots \ldots \ldots \ldots \ldots \ldots \ldots \ldots \ldots
\end{aligned}
$$

Dimana Y adalah

Kemiskinan Desa, $\beta_{0}$ adalah Konstanta/Intercept, $\beta_{1}, \beta_{2}, \beta_{3}$ adalah Koefisien Regresi Parsial, $X_{1}$ adalah Dana Desa dan $X_{2}$ adalah Alokasi Dana Desa. dalam persamaan regresi juga dimasukkan variabel dummy berupa tahun penelitian dengan tujuan untuk mengetahui ada tidaknya perubahan kemiskinan desa pada 2015 dan 2016.

Analisis data dilakukan dengan metode Common Effect, Fixed Effect, dan Random Effect, uji kriteria model menggunakan uji LM Breush-Pagan, uji Chow, dan uji Hausman. Uji statistik antara lain Uji $\mathrm{t}$, Uji $\mathrm{F}$, dan R2 (koefisien determinasi) untuk mengetahui bagaimanakah pengaruh variabel bebas terhadap vaiabel terikat secara simultan (serentak) maupun secara parsial (masing-masing variabel).

\section{PEMBAHASAN}

Berikut adalah profil gambaran mengenai kemiskinan desa, Dana Desa, dan Alokasi Dana Desa (ADD) di Kabupaten Tulungangung. 
1. Kemiskinan Desa di Lima desa dengan kenaikan Kabupaten Tulungagung kemiskinan desa tertinggi dijelaskan Tahun 2015-2016

Kemiskinan desa di dalam Tabel 1.

Berdasarkan Tabel 1 diketahui Kabupaten Tulungagung rata-rata mengalami kenaikan dari Tahun 2015 ke 2016. Pada Tahun 2015 angka kemiskinan desa sebesar 1.080 jiwa, sedangkan Tahun 2016 meningkat sebanyak 58 jiwa. Sehingga angka kemiskinan desa bahwa jumlah kenaikan penduduk miskin terbesar berada di Desa Pakel mengalami kenaikan kemiskinan desa sebesar 864 jiwa atau 209,60\%, yaitu pada Tahun 2015 yaitu sebesar 412 jiwa yang kemudian meningkat di Tahun 2016 menjadi 1.276 jiwa. pada Tahun 2016 sebesar 1.137 jiwa.

Tabel 1. Kenaikan Kemiskinan Desa di Kabupaten Tulungagung Tahun 2015-2016 (Jiwa)

\begin{tabular}{llcccc}
\hline \multirow{2}{*}{ No } & \multirow{4}{*}{$\begin{array}{c}\text { Desa } \\
\text { Menduduk }\end{array}$} & \multicolumn{2}{c}{$\boldsymbol{\Delta}$} \\
\cline { 3 - 6 } & & $\mathbf{2 0 1 5}$ & $\mathbf{2 0 1 6}$ & Jumlah & $\%$ \\
\hline 1 & Pakel & 412 & 1.276 & 864 & $209,60 \%$ \\
\hline 2 & Sitoyobagus & 455 & 953 & 498 & $109,43 \%$ \\
\hline 3 & Pecuk & 365 & 732 & 367 & $100,51 \%$ \\
\hline 4 & Sumberagung & 2.220 & 2.462 & 242 & $10,90 \%$ \\
\hline 5 & Srikaton & 1.930 & 2.149 & 219 & $32,72 \%$ \\
\hline $\begin{array}{l}\text { Sumber: Badan Perencanaan Pembangunan Daerah } 2015-2016 \text { (data } \\
\text { diolah) }\end{array}$
\end{tabular}

Sedangkan Desa yang Jenglungharjo mengalami penurunan menurun jumlah kemiskinan desa kemiskinan desa sebesar 507 jiwa dijelaskan dalam Tabel 2. atau sebesar $25,25 \%$, yaitu dengan Berdasarkan Tabel 2 diketahui jumlah 2.007 jiwa pada Tahun 2015 bahwa jumlah penurunan kemiskinan kemudian menurun menjadi 1.500 desa terbesar berada di Desa jiwa pada Tahun 2016.

Tabel 2 Penurunan Kemiskinan Desa di Kabupaten Tulungagung Tahun 2015-2016 (Jiwa)

\begin{tabular}{lcccrc}
\hline \multirow{2}{*}{ No } & \multirow{2}{*}{ Desa } & \multicolumn{2}{c}{$\begin{array}{c}\boldsymbol{2} \text { Penduduk } \\
\text { Miskin }\end{array}$} & \multicolumn{2}{c}{$\Delta$} \\
\cline { 3 - 6 } & & $\mathbf{2 0 1 5}$ & $\mathbf{2 0 1 6}$ & Jumlah & $\%$ \\
\hline 1 & Jenglungharjo & 2.007 & 1.500 & -507 & $-25,25 \%$ \\
\hline
\end{tabular}




\begin{tabular}{|c|c|c|c|c|c|}
\hline 2 & Wateskroyo & 799 & 318 & -481 & $-60,20 \%$ \\
\hline 3 & Tanggulwelahan & 1.206 & 787 & -419 & $-34,78 \%$ \\
\hline 4 & Tanggunggunung & 1.623 & 1.213 & -410 & $-25,25 \%$ \\
\hline 5 & Pakisrejo & 1.187 & 887 & -300 & $-25,25 \%$ \\
\hline 6 & Ngrejo & 1.149 & 859 & -290 & $-25,25 \%$ \\
\hline 7 & Ngepoh & 1.095 & 819 & -276 & $-25,25 \%$ \\
\hline 8 & Suwaluh & 704 & 428 & -276 & $-39,16 \%$ \\
\hline 9 & Kresikan & 1.085 & 811 & -274 & $-25,25 \%$ \\
\hline 10 & Gombang & 1.227 & 1.034 & -193 & $-15,70 \%$ \\
\hline 11 & Tenggarejo & 555 & 415 & -140 & $-25,25 \%$ \\
\hline 12 & Besole & 2.356 & 2.319 & -37 & $-1,56 \%$ \\
\hline 13 & Kasreman & 389 & 379 & -10 & $-2,46 \%$ \\
\hline
\end{tabular}

Sumber: Badan Perencanaan Pembangunan Daerah 2015-2016 (data diolah)

Berdasarkan data dapat

diketahui bahwa Dana Desa dan ADD efektif dan berhasil dalam mengentaskan kemiskinan pada tiga belas desa tersebut.

2. Dana Desa di Kabupaten Tulungagung Tahun 20152016

Tabel 3. Kenaikan Dana Desa Terbesar di Kabupaten Tulungagung Tahun 2015-2016 (Rupiah)

\begin{tabular}{llcccc}
\hline \multirow{2}{*}{ No } & \multirow{2}{*}{ Desa } & \multicolumn{2}{c}{ Dana Desa } & \multicolumn{2}{c}{$\boldsymbol{\Delta}$} \\
\cline { 3 - 6 } & & $\mathbf{2 0 1 5}$ & $\mathbf{2 0 1 6}$ & Jumlah & \% \\
\hline 1 & Ngrejo & 276.471 .383 & 670.525 .000 & 394.053 .617 & $142,53 \%$ \\
\hline 2 & Ngunut & 328.455 .959 & 721.313 .000 & 392.857 .041 & $119,61 \%$ \\
\hline 3 & Rejoagung & 296.648 .211 & 679.361 .000 & 382.712 .789 & $129,01 \%$ \\
\hline 4 & Jenglungharjo & 296.324 .306 & 677.783 .000 & 381.458 .694 & $128,73 \%$ \\
\hline 5 & Keboireng & 272.881 .494 & 649.151 .000 & 376.269 .506 & $137,89 \%$ \\
\hline
\end{tabular}

Sumber: Dinas Pemberdayaan Masyarakat dan Pemerintahan Desa 2015-2016 (data diolah)

Berdasarkan Tabel 3

diketahui bahwa kenaikan Dana

Desa terbesar antara Tahun 2015-

2016 adalah Desa Ngrejo mengalami kenaikan sebesar 394.053.617 atau sebesar 142,53\%, yaitu sebesar
Kabupaten Tulungagung pada Tahun 2015-2016 rata-rata mengalami kenikan sebesar Rp344.742.275. (DD) tertinggi dijelaskan dalam tabel berikut. Desa dengan kenaikan Dana Desa 
Tabel 4 . Kenaikan Dana Desa Terendah di Kabupaten Tulungagung 2015-2016 (Rupiah)

\begin{tabular}{cccccc}
\hline \multirow{2}{*}{ No } & \multirow{2}{*}{ Desa } & \multicolumn{2}{c}{ Dana Desa } & \multicolumn{2}{c}{$\boldsymbol{\Delta}$} \\
\cline { 3 - 6 } & & $\mathbf{2 0 1 5}$ & $\mathbf{2 0 1 6}$ & Jumlah & \% \\
\hline 1 & Sukoanyar & 261.557 .384 & 591.072 .000 & 329.514 .616 & $125,98 \%$ \\
\hline 2 & Pecuk & 261.726 .789 & 591.230 .000 & 329.503 .211 & $125,90 \%$ \\
\hline 3 & Samir & 267.541 .780 & 595.342 .000 & 327.800 .220 & $122,52 \%$ \\
\hline 4 & Bukur & 281.003 .111 & 606.193 .000 & 325.189 .889 & $115,72 \%$ \\
\hline 5 & Simo & 337.556 .600 & 605.297 .000 & 267.740 .400 & $79,32 \%$ \\
\hline
\end{tabular}

Sumber: Dinas Pemberdayaan Masyarakat dan Pemerintahan Desa 2015 2016 (data diolah)

Berdasarkan tabel 4 dapat diketahui bahwa kenaikan Dana Desa terbesar antara Tahun 20152016 adalah berada di Desa Ngrejo mengalami kenaikan sebesar 394.053.617 atau sebesar 142,53\%, yaitu sebesar 276.471 .383 pada tahun 2015 mengalami kenaikan sebesar 670.525.000 pada Tahun 2016.

Dana Desa (DD) pada Tahun 2015-2016 secara umum mengalami peningkatan rata-rata $79 \%$ sampai $142 \%$, hal tersebut dikarenakan pada kebijakan mengenai pengalokasian
Dana Desa diukur berdasarkan jumlah penduduk, luas wilayah, angka kemiskinan dan tingkat kesulitan geografis.

\section{Alokasi Dana Desa (ADD) di Kabupaten Tulungagung} Tahun 2015-2016

Alokasi Dana Desa (ADD) di Kabupaten rata-rata mengalami kenaikan dari Tahun 2015 ke 2016 sebesar Rp249.774.725. Desa dengan kenaikan Alokasi Dana Desa (ADD) tertinggi dijelaskan dalam tabel berikut.

Tabel 5. Kenaikan Alokasi Dana Desa (ADD) Tertinggi di Kabupaten Tulungagung Tahun 2015-2016 (Rupiah)

\begin{tabular}{cccccc}
\hline \multirow{2}{*}{ No } & \multirow{2}{*}{ Desa } & \multicolumn{2}{c}{ ADD } & \multicolumn{2}{c}{$\Delta$} \\
\cline { 3 - 6 } & & $\mathbf{2 0 1 5}$ & $\mathbf{2 0 1 6}$ & Jumlah & \% \\
\hline 1 & Kresikan & 182.400 .000 & 901.400 .000 & 719.000 .000 & $394,19 \%$ \\
\hline 2 & Demuk & 189.690 .000 & 816.200 .000 & 626.510 .000 & $330,28 \%$ \\
\hline 3 & Pakisrejo & 186.360 .000 & 812.800 .000 & 626.440 .000 & $336,15 \%$ \\
\hline 4 & Pucanglaban & 182.040 .000 & 781.400 .000 & 599.360 .000 & $329,25 \%$ \\
\hline 5 & Sumberdadap & 173.000 .000 & 696.000 .000 & 523.000 .000 & $302,31 \%$ \\
\hline $\begin{array}{l}\text { Sumber: Dinas Pemberdayaan Masyarakat dan Pemerintahan Desa } \\
\text { 2016 (data diolah) }\end{array}$
\end{tabular}


Berdasarkan Tabel 5 dapat diketahui bahwa kenaikan Alokasi Dana Desa terbesar antara Tahun 2015-2016 berturut-turut adalah Desa Kresikan mengalami kenaikan sebesar Rp719.000.000 atau sebesar 394,19\%, yaitu sebesar
Rp182.400.000 pada tahun 2015 menjadi Rp901.400.000 pada Tahun 2016.

Sedangkan desa dengan kenaikan Alokasi Dana Desa (ADD) terendah dijelaskan dalam tabel berikut.

Tabel 6. Kenaikan Alokasi Dana Desa (ADD) Terendah di Kabupaten Tulungagung Tahun 2015-2016 (Rupiah)

\begin{tabular}{llcccc}
\hline \multirow{2}{*}{ No } & \multirow{2}{*}{ Desa } & \multicolumn{2}{c}{ ADD } & \multicolumn{2}{c}{$\boldsymbol{\Delta}$} \\
\cline { 3 - 6 } & & $\mathbf{2 0 1 5}$ & $\mathbf{2 0 1 6}$ & Jumlah & \% \\
\hline 1 & Samir & 321.748 .000 & 392.300 .000 & 70.552 .000 & $21,93 \%$ \\
\hline 2 & Bukur & 346.984 .000 & 416.800 .000 & 69.816 .000 & $20,12 \%$ \\
\hline 3 & Buntaran & 405.020 .000 & 455.000 .000 & 49.980 .000 & $12,34 \%$ \\
\hline 4 & Mojoagung & 358.712 .000 & 402.700 .000 & 43.988 .000 & $12,26 \%$ \\
\hline 5 & Gempolan & 388.808 .000 & 426.800 .000 & 37.992 .000 & $9,77 \%$ \\
\hline
\end{tabular}

Sumber: Dinas Pemberdayaan Masyarakat dan Pemerintahan Desa 20152016 (data diolah)

Desa dengan kenaikan Alokasi

Dana Desa terendah adalah Desa Samir dengan kenaikan sebesar Rp70.552.000 atau sebesar 21,93\%, yaitu sebesar Rp321.748.000 pada tahun 2015 mengalami kenaikan menjadi Rp392.300.000 pada Tahun 2016.

Alokasi Dana Desa (ADD) untuk seluruh Desa di Kabupaten Tulungagung rata-rata mengalami peningkatan pada Tahun 2015 ke 2016 antara 9\% sampai dengan 394\%. Hal tersebut dikarenakan perubahan kebijakan Pemerintah
Daerah Kabupaten Tulungagung pada Tahun 2016.

Berdasarkan hasil regresi menggunakan program Eviews diketahui hasil estimasi menggunakan Teknik Common Effect, Fixed Effect, dan Random Effect adalah sebagai berikut:

1. Model Common Effect

$$
\begin{aligned}
& Y=-74,26+9,17 X_{1}- \\
& 0,025 X_{2}-3,18 D_{i}+e
\end{aligned}
$$

2. Model Fixed Effect

$$
\begin{aligned}
& Y=-8,40-0,57 X_{1}- \\
& 0,07 X_{2}+0,24 D_{i}+e \ldots .
\end{aligned}
$$

3. Model Random Effect 


$$
\begin{aligned}
& Y=-29,42+3,88 X_{1}- \\
& 0,04 X_{2}-1,32 D_{i}+e \ldots \ldots
\end{aligned}
$$

Untuk memilih model panel mana yang sesuai paling sesuai untuk digunakan dalam model, maka perlu dilakukan perbandingan antara model-model Common Effect, Fixed Effect, dan Random Effect dengan menggunakan Uji LM Breush-Pagan, Uji Chow dan Uji Hausman untuk mengetahui model terbaik yang akan digunakan dalam mengestimasi pengaruh variabel.

1. Uji LM Breush-Pagan

Uji LM Breush-Pagan digunakan untuk menentukan model dengan metode Common Effect atau Random Effect yang paling tepat digunakan dalam mengestimasi data panel.

Tabel 7. Hasil Uji LM Breush-Pagan

\begin{tabular}{llll}
\hline & \multicolumn{3}{c}{ Test Hypothesis } \\
\cline { 2 - 4 } Breusch-Pagan & Cross-section & Time & Both \\
\cline { 2 - 4 } & 107.3666 & 0.116427 & 107.4830 \\
\cline { 2 - 4 } & $(0.0000)$ & $(0.7329)$ & $(0.0000)$ \\
\hline
\end{tabular}

Sumber: output regresi

Berdasarkan Uji Breusch Pagan, diperoleh Prob. Breush Pagan sebesar $=0.0000$. Nilai tersebut lebih kecil dari $\alpha=0.05$, sehingga diputuskan untuk menolak Berdasarkan Uji Chow diperoleh Prob.F $=0.0000$. Nilai tersebut lebih demikian, dapat dikatakan bahwa model Fixed Effect lebih tepat
Ho. Dengan demikian, dapat dikatakan bahwa model Random Effect Lebih sesuai digunakan daripada model Common Effect.

\section{Uji Chow} kecil $\alpha=0.05$, sehingga diputuskan untuk menolak Ho. Dengan digunakan daripada model Common Effect

Tabel 8 : Hasil Uji Chow

\begin{tabular}{lcrc}
\hline Effects Test & Statistic & d.f. & Prob. \\
\hline Cross-section F & 2303.321089 & $(126,124)$ & 0.0000 \\
\hline Sumber: output regresi & & &
\end{tabular}

3. Uji Hausman

Berdasarkan hasil estimasi model dengan metode Fixed Effect dan Random Effect, maka dalam penelitian ini dilakukan dengan pengujian Hausman test. Uji Hausman dilakukan untuk memilih kesesuaian model menggunakan Fixed Effect atau Random Effect. 


\section{Tabel 9 : Hasil Uji Hausman}

\begin{tabular}{lcrc}
\hline Test Summary & Chi-Sq. Statistic Chi-Sq. d.f. & Prob. \\
\hline Cross-section random & 0.000000 & 3 & 0.0000 \\
\hline Sumber: output regresi & &
\end{tabular}

Berdasarkan uji Hausman, Variabel Dana Desa diperoleh Prob. $=0.0000$. Nilai berpengaruh negatif dan signifikan tersebut lebih kecil dari $\alpha=0.05$, terhadap kemiskinan desa. Koefisien sehingga diputuskan untuk menerima sebesar $-0,57$, memberikan indikasi Ho. Dengan demikian, dapat jika setiap penambahan $1 \%$ Dana dikatakan bahwa model Fixed Effect lebih tepat digunakan dari pada model Random Effect.

Dari ketiga uji yang dilakukan, maka diambil kesimpulan bahwa model yang paling sesuai adalah model Fixed Effect.

Dengan hasil Fixed Effect Model tersebut kemudian dilakukan Uji t, Uji F, dan R-Square pada output Fixed Effect, berdasarkan model persamaan untuk Fixed Effect (persamaan 3).

Kemiskinan desa di kabupaten Tulungagung jika diasumsikan nilai variabel Dana Desa, Alokasi Dana Desa dan dummy adalah nol ditentukan oleh besarnya nilai intercept $\left(\beta_{0}\right)$. Nilai intercept pada model Fixed Effect adalah 8,40. Ini berarti jika Dana Desa, Alokasi Dana Desa dan dummy bernilai nol, maka akan meningkatkan kemiskinan desa sebesar $8,40 \%$. Desa, maka akan menurunkan kemiskinan desa sebesar $0,57 \%$. Dimana nilai tersebut sesuai dengan hipotesis bahwa jika Dana Desa naik maka akan menurunkan kemiskinan desa.

Variabel Alokasi Dana Desa berpengaruh negatif dan signifikan terhadap kemiskinan desa. Koefisien sebesar $-0,07$ ini memberikan indikasi jika setiap penambahan $1 \%$ Alokasi Dana Desa, maka akan menurunkan kemiskinan desa sebesar $0,07 \%$. Dimana nilai tersebut sesuai dengan hipotesis bahwa jika Alokasi Dana Desa naik maka akan menurunkan kemiskinan desa.

$$
\text { Variabel dummy }
$$
berpengaruh positif dan signifikan terhadap kemiskinan desa. Koefisien sebesar 0,24, memberikan indikasi bahwa jika variabel Dana Desa dan Alokasi Dana Desa bernilai nol, 
maka kemiskinan desa akan mengalami peningkatan dari Tahun 2015 ke 2016 sebesar 0,24 jiwa. Dimana nilai tersebut sesuai dengan hipotesis bahwa jika terjadi perbedaan kemiskinan desa Tahun 2015 dengan 2016.

Berikut adalah hasil regresi menggunakan model Fixed Effect diperoleh hasil Uji t, Uji F, dan RSquared sebagai berikut:

\section{Uji F}

Uji F merupakan salah satu uji statistik yang digunakan untuk melihat pengaruh semua variabel secara bersama-sama yaitu variabel independen antara lain Dana Desa, Alokasi Dana Desa dan dummy terhadap variabel dependen (variabel terikat) yaitu kemiskinan desa di Kabupaten Tulungagung. Selanjutnya hasil dari uji secara simultan (bersama-sama). Hasil uji regresi dengan melihat probabilitas $\mathrm{F}$ statistik $=0.0000 \leq$ nilai probabilitas $\alpha=5 \%$, berarti $\mathrm{H}_{1}$ diterima yang artinya seluruh variabel bebas yaitu Dana Desa (DD), Alokasi Dana Desa (ADD), jumlah penduduk dan dummy berpengaruh signifikan terhadap kemiskinan desa.

2. Uji t
Tujuan dilakukan uji $\mathrm{t}$ dalam penelitian ini adalah untuk menguji secara parsial (sendiri-sendiri) pengaruh variabel bebas yaitu Dana Desa (DD), Alokasi Dana Desa (ADD), jumlah penduduk dan dummy terhadap variabel terikat yaitu kemiskinan desa. Hasil Uji t sebagai berikut:

a. Variabel Dana Desa (X1)

Probabilitas $\mathrm{t}$ hitung variabel Dana Desa $=0,0000 \leq$ nilai probabilitas $\alpha=5 \%$ maka Ho ditolak dan $\mathrm{H}_{1}$ diterima yang artinya variabel Dana Desa (DD) berpengaruh signifikan terhadap kemiskinan desa.

b. Variabel Alokasi Dana Desa (X2)

Probabilitas $\mathrm{t}$ hitung sebesar $0,0000 \leq$ nilai probabilitas $\alpha=5 \%$ maka $\mathrm{Ho}$ ditolak dan $\mathrm{H}_{1}$ diterima yang artinya variabel Alokasi Dana Desa (ADD) berpengaruh signifikan terhadap kemiskinan desa.

c. Variabel Dummy (Di)

Probabilitas $\mathrm{t}$ hitung sebesar $0,0000 \leq$ nilai probabilitas $\alpha=5 \%$ maka Ho ditolak dan $\mathrm{H}_{1}$ diterima yang artinya variabel dummy berpengaruh signifikan terhadap kemiskinan desa. 
Hasil Uji $\mathrm{t}$ menunjukkan terikat, secara keseluruhan dapat bahwa tiga variabel bebas dilihat dari Tabel 10. berpengaruh terhadap variabel

Tabel 10. Hasil Uji t pada Model Common Effect

Variabel Koefisien Probabilitas $\begin{gathered}\text { Signifikasi } \\ (\alpha=0.05 \%)\end{gathered}$ Keterangan

\begin{tabular}{ccccc}
\hline Dana Desa & $-0,5730$ & 0,0000 & 0,05 & Berpengaruh \\
\hline ADD & $-0,0701$ & 0,0000 & 0,05 & Berpengaruh \\
\hline Dummy & 0,0246 & 0,0000 & 0,05 & Berpengaruh \\
\hline
\end{tabular}

Sumber: hasil analisis data menggunakan program Eviews (diolah)

3. Pengujian Koefisien

Determinasi $\left(\mathrm{R}^{2}\right)$

Koefisien determinasi $\left(\mathrm{R}^{2}\right)$ pada umumnya digunakan untuk mengukur seberapa jauh kemampuan model dalam menerangkan variasi variabel dependen. Nilai koefisien determinasi adalah nol (0) dan (1). Hasil perhitungan pada tabel 4.6 menunjukkan nilai R-squared = 0,9999 dengan demikian dapat diartikan bahwa total variasi kemiskinan desa di Kabupaten Tulungagung dapat dijelaskan oleh variabel independen Dana Desa (DD), Alokasi Dana Desa (ADD) dan dummy sebesar 99\% sedangkan sisanya $1 \%$ dijelaskan oleh variabel lain di luar model yang digunakan.

\section{PENUTUP}

\section{Kesimpulan}

Berdasarkan hasil analisis data dan pembahasan yang telah dilakukan dapat diketahui bahwa sesuai dengan tujuan penelitian yaitu untuk menganalisis pengaruh Dana Desa terhadap kemiskinan desa di Kabupaten Tulungagung tahun 20152016, serta untuk menganalisis perbedaan kemiskinan desa di Kabupaten Tulungagung antara Tahun 2015 dengan 2016 maka kesimpulan yang dapat diambil dari penelitian ini adalah bahwa hasil dari uji hipotesis menggunakan uji secara parsial (Uji t) dan uji simultan (Uji F) menunjukkan bahwa variabel Dana Desa berpengaruh signifikan terhadap kemiskinan desa di Kabupaten Tulungagung pada Tahun 2015-2016 serta terjadi perbedaan kemiskinan desa di Kabupaten Tulungagung antara Tahun 2015 dengan 2016.

Dana Desa dan ADD efektif dan berhasil dalam mengurangi 
kemiskinan desa pada 13 desa di Kabupaten Tulungagung, yaitu Desa Jengglungharjo, Wateskroyo, Tanggulwelahan, Tanggunggunung, Pakisrejo, Ngrejo, Ngepoh, Suwaluh, Kresikan, Gombang, Tenggarejo, Besole, dan Kasreman. Sedangkan sisanya sebanyak 114 desa, Dana Desa tidak efektif dalam mengurangi kemiskinan desa, hal tersebut dikarenakan penggunaan Dana Desa sebagian besar digunakan untuk pembangunan sarana dan prasarana fisik perdesaan (84 persen), sementara penggunaan bagi pemberdayaan ekonomi masyarakat masih terbilang kecil yaitu sebesar 6,5 persen. Selain itu, kualitas sarana dan prasarana yang dibangun masih kurang baik karena minimnya kemampuan teknis pengelola, baik dari sisi perencanaan dan pengelolaannya.

Diketahui bahwa Dana Desa berpengaruh negatif sebesar $-4,52$, Alokasi Dana Desa berpengaruh negatif sebesar $-1,52$ dan koefisien dummy berpengaruh $\quad-56,07$, menunjukkan bahwa terjadi perbedaan kemiskinan desa di Kabupaten Tulungagung antara Tahun 2015 dengan 2016. Dengan nilai koefisien determinasi $\left(\mathrm{R}^{2}\right)$ menunjukkan bahwa sebesar 0,99 atau $99 \%$ variabel bebas yaitu Dana Desa dapat menjelaskan kemiskinan desa di Kabupaten Tulungagung. Sedangkan 0,01 atau $1 \%$ sisanya dijelaskan oleh variabel lain yang tidak diikutkan dalam penelitian ini.

\section{DAFTAR PUSTAKA}

Abidin, Muhammad Zainul. 2015. "Tinjauan atas Pelaksanaan Keuangan Desa dalam Mendukung Kebijakan Dana Desa". Jurnal Ekonomi \& Kebijakan Publik. Vol. 6 No. 1, hlm 61-76.

Adisasmita, Rahardjo. 2006. Membangun Desa Partisipatif. Yogyakarta: Graha Ilmu.

Arsyad, L. 2004. Ekonomi Pembangunan. Yogyakarta: Yayasan Keluarga Pahlawan Negara.

Astuti, P. B. 2012. Efektivitas dan Pengaruh PNPM Mandiri Perdesaan, Alokasi Dana Desa, Pendapatan Asli Desa dan Jumlah Penduduk Terhadap Jumlah Keluarga Miskin di Kabupaten Kebumen Tahun 2009-2011. Jurnal Admisnistrasi Publik, 19.

Azwardi, \& Suntoko. 2014. Efektifitas Alokasi Dana Desa (ADD) dan Kemiskinan di Provinsi Sumatera Selatan. Jurnal Ekonomi Pembangunan, 29-41. 
Badan Perencanaan Pembangunan Daerah. 2015. 2016.

Badan Pusat Statistik. 2007. "Kemiskinan".

http://www.bps.go.id

2014. Statistik

Keuangan Pemerintah Desa 2013.

Beratha, I Nyoman. 1982. Desa Masyarakat Desa dan Pembangunan Desa. Jakarta: Ghalia Indonesia.

Dinas Pemberdayaan Masyarakat Desa. 2015. 2016 .

Dura, J. (2016). Pengaruh Akuntabilitas Pengelolaan Keuangan Alokasi Dana Desa, Kebijakan Desa, dan Kelembagaan Desa terhadap Kesejahteraan Masyarakat. JIBEKA, 26-32.

Fuad, Noor, dkk. . 2014. Dasardasar Keuangan Publik. Jakarta: LPKAP-Badan Pendidikan dan Peatihan Keuangan.

Gujrati, Damodar N. \& Dawn C. Porter. 2011. Dasar - dasar Ekonometrika : Edisi 5-Buku 1 Jakarta: Salemba Empat.

2012. Dasar dasar Ekonometrika : Edisi 5Buku 2. Jakarta: Salemba Empat.

Irawan, \& Suparmoko. 2006. Ekonomi Pembangunan. Yogyakarta: BPFE.
Haughton, Jonathan \& Shahidur R. Khander. 2010. Pedoman tentang Kemiskinan dan Ketimpangan. Jakarta: Salemba Empat

Kamus Besar Bahasa Indonesia (KBBI).

Kementerian Dalam Negeri. Buku induk kode data wilayah 2013: Permendagri Nomor 18/2013. Jakarta: Kementerian Dalam Negeri. 2013.

Khusaini, Mohammad. 2006. Ekonomi Publik Desentralisasi Fiskal dan Pembangunan Daerah. Malang: Badan Penerbit Fakultas Ekonomi Universitas Brawijaya.

Kuncoro, M. 1997. Ekonomi Pembangunan; Teori, Masalah, dan Kebijakan. Yogyakarta: UPP AMP YKPN.

2013. Metode Riset
untuk Bisnis dan Ekonomi
Edisi 4. Jakarta: Erlangga.

Mustikawati. 2016. Partisipasi Masyarakat dalam Pembangunan Infrastruktur Desa di Desa Rapak Lambur Kecamatan Tenggarong Kabupaten Kutai Kartanegara. Jurnal Ilmu Administrasi Negara. Vol. 4 No. 2, hlm 2739-2752.

Nuraini, I. 2013. Pengantar Ekonomi Mikro. Malang: UMM Press.

Nurman. 2015. Strategi

Pembangunan Daerah. Jakarta:

Rajawali Pers.

Peraturan Menteri Dalam Negeri Nomor 37 Tahun 2007 tentang 
Pedoman Pengelolaan

Keuangan Desa.

Peraturan Menteri Dalam Negeri Nomor 113 Tahun 2014 tentang Pengelolaan Keuangan Desa.

Peraturan Pemerintah Nomor 60 tahun 2014 tentang Dana Desa yang Bersumber dari Anggaran Pendapatan dan Belanja Negara

Prasetyo, Yudhi \& Gregorius Nasiansenus Masdjojo. 2014. Implementasi Kebijakan Alokasi Dana Desa di 10 Desa Wilayah Kecamatan Rembang Kabupaten Rembang. Jurnal Administrasi Publik. Vol. 1 No. 6, hlm 302-319.

Putra, Chandra Kusuma, dkk. 2013. Pengelolaan Dana Desa dalam Pemberdayaan Masyarakat Desa (Studi pada Desa Wonorejo Kecamatan Singosari Kabupaten Malang). Jurnal Administrasi Publik. Vol. 1 No. 6, hlm 1203-1212.
Sajogyo. 1997. Kemiskinan dan kebutuhan Minum Pangan. Bogor: Lembaga Penelitian Sosiologi Pedesaan.

Sari, Risya Novita, dkk. 2012. Pengelolaan Dana Desa dalam Perspektif Pemberdayaan Masyarakat (Studi pada Kantor Pemerintah Desa Ngasem, Kecamatan Ngasem, Kabupaten Kediri). Jurnal Administrasi Publik. Vol. 3 No. 11, hlm 1880-1885.

Sujarweni, V. Wiratna. 2015. Akuntansi Desa Panduan Tata Kelola Keuangan Desa.

Yogyakarta. Pustaka Baru Press Yogyakarta

Todaro, M. P. 2000. Pembangunan Ekonomi 1. Jakarta: Bumi Aksara.

Undang-Undang Republik Indonesia Nomor 6 Tahun 2014 Tentang Desa.

Widjaja, HAW. 2003. Otonomi Desa. Jakarta: Rajawali Pers 